\title{
DEVELOPMENT OF MEAT-CONTAINING BREADS WITH HEMP SEED FLOUR AND TURKEY MEAT OF MECHANICAL CRUMBING
}

\author{
Nataliia Bozhko \\ The Department of Biophysics, Biochemistry, Pharmacology \\ and Biomolecular Engineering \\ Medical Institute \\ Sumy State University \\ 31 Sanatornaya str., Sumy, Ukraine, 40018 \\ Vasyl Pasichnyi ${ }^{1}$ \\ Vasyl Tischenko \\ Andriy Marynin $\bowtie$ \\ Problem research laboratory ${ }^{2}$ \\ andrii_marynin@ukr.net \\ Yevgenia Shubina ${ }^{3}$ \\ Igor Strashynskyi ${ }^{1}$ \\ ${ }^{1}$ Department of technology of meat and meat products ${ }^{2}$ \\ ${ }^{2}$ National University of Food Technologies \\ 68 Volodumurska str., Kyiv, Ukraine, 01601 \\ ${ }^{3}$ Department of technology and food safety \\ Sumy National Agricultural University \\ 160 G. Kondratieva str., Sumy, Ukraine, 40021
}

$\triangle$ Corresponding author

Abstract

The work is devoted to the development of meat-containing breads with a combination of turkey MCPM (mechanically crumbed poultry meat) and hemp flour with further study of functional-technological and sensory characteristics and the study of nutritional and energy value of finished products. The aim of the study was to investigate the effectiveness of the use of hemp seed flour in the technology of baked meat products.

It was proved, that the combination of turkey MCPM and hemp flour in meat-containing breads allows to produce products with high nutritional characteristics. It was found, that the introduction of turkey in the recipe of MCPM in combination with hemp seed flour allows to obtain bread with a mass fraction of protein 18.03-19.53 g/100 g of the product. The protein concentration in the experimental samples exceeded the analogue by $3.21-11.79 \%$. The fraction of fat in meat-containing breads increased by an average of $37 \%$ due to the inclusion of turkey in the recipe of MCPM. The inclusion of turkey MCPM in the recipe up to $47 \%$ increases the concentration of macro- and micronutrients in bread to $2.06 \pm 0.05 \mathrm{~g} / 100 \mathrm{~g}$.

The inclusion of hemp flour in the recipe of baked products with a high content of turkey MCPM improves the functional, technological and organoleptic properties of the products. The increase in protein content by $3.21-11.80 \%$, fat - by $47.84-$ $56.83 \%$, energy value - by $26.52-30.23 \%$ was determined.

The high efficiency of combining turkey MCPM with hemp seed flour was confirmed in the study of functional and technological properties (FTP) of model minced meat. The ratio of MCMP: hemp seed flour 41: 8, 44:10, 47:12 improves WBC (water-binding capacity) by $13.46-22.15 \%$, WRC (water-retaining capacity) - by $10.34-21.43 \%$, FRC (fat-retaining capacity) - by $17.2-26.9 \%$. It was established, that the best indicators of FTP of minced meat and finished products were obtained by including 
$44 \%$ of turkey MCPM and $10 \%$ of hemp flour in the recipe of meat-containing bread. The results of the organoleptic analysis of the developed breads confirmed their high consumer value.

Keywords: hemp flour, meat-rich breads, turkey MCPM, technological indicators, functional and technological properties.

DOI: $10.21303 / 2504-5695.2021 .001977$

\section{Introduction}

The spread of pathological conditions, associated with a lack or excess of essential nutrients, has stimulated the promotion of a balanced diet and a healthy lifestyle in general. This in turn has increased demand for a range of foods. Manufacturers are faced with the task of satisfying the consumer's desire to eat healthily and safely. In conditions of protein-energy deficiency, functional products, based on raw meat, become especially important $[1,2]$.

An urgent task in the field of food technology is the use of non-traditional raw materials, with which it would be possible to create healthy food products. One of protein ingredients of plant origin for the production of combined meat-containing products can be hemp seeds [3, 4]. The low content of cannabiol (less than $0.5 \%$ ) and high protein concentration (about $40 \%$ ) led to the use of seeds of Cannabis Sativa L. and its products in the baking and confectionery industries $[5,6]$. As a plant source of protein and an alternative to soy products, hemp seeds can be an effective meat substitute for warm-blooded animals in the development of functional meat products.

Therefore, the aim of the study was to investigate the effectiveness of the use of hemp seed flour in the technology of baked meat products. The task was to assess the impact of different concentrations of hemp flour on the nutritional value, functional-technological, technological, structural-mechanical and organoleptic properties of the developed products.

\section{Materials and Methods}

Three samples of meat-containing breads with different hemp flour content were developed. As an analogue, meat-containing bread from combined raw materials was used [7]. The ratios of the components of the analogous recipe and model samples are given in Table $\mathbf{1 .}$

Table 1

The recipe ratio of the ingredients of experimental meat-containing breads

\begin{tabular}{ccccc}
\hline Components & \multicolumn{3}{c}{ Recipe variants } \\
\cline { 2 - 5 } & Unsalted pork, kg for 100 kg & & $\mathbf{2}$ & $\mathbf{3}$ \\
\hline Semi-fatty tendon-free pork & - & 35 & 30 & 25 \\
Tendon-free duck & 30 & - & - & - \\
Minced silver carp & 45 & - & - & - \\
MCPM (turkey) & - & 41 & 44 & 47 \\
Side lard & 10 & 10 & 10 & 10 \\
Dry whey & 5 & - & - & - \\
Pumpkin pulp paste & - & 3 & 3 & 3 \\
Hemp flour & - & 8 & 10 & - \\
Wheat flour & 2 & - & 3 & - \\
Chicken eggs or mélange & 3 & - & - & -
\end{tabular}

To make minced meat, duck, fish and pork were minced in a laboratory meat grinder (Philipps, Germany), after which dry ingredients were added. Hydration of hemp flour was performed with warm $\left(35-40^{\circ} \mathrm{C}\right)$ water for 15 minutes, hydromodule 1: 3 . 
Nutmeg pumpkin paste was made from purified pulp using a blender. Side lard was frozen and crushed into pieces measuring $3 \times 3 \mathrm{~mm}$. The crushed components were stirred for 8 minutes, salt and spices were added to the minced meat. After cooking, the minced mass was filled into pans, pre-greased with lard (Fig. 1).

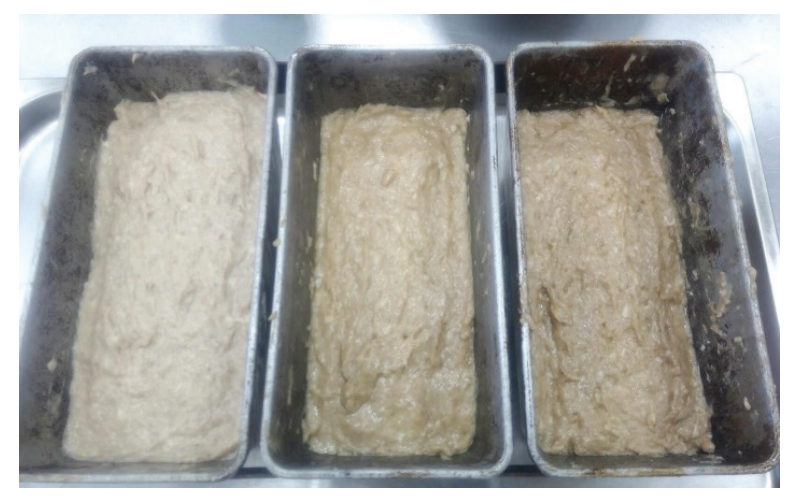

Fig. 1. Experimental model samples of minced meat before heat treatment $(1,2,3)$

Baking of bread was carried out in three stages with the total process duration of 210 220 minutes, until the temperature in the thickness of the product reached $70-72{ }^{\circ} \mathrm{C}$. After heat treatment, the loaves were removed from the pan and cooled to a temperature in the deep product in the range of $4-8{ }^{\circ} \mathrm{C}$.

Hemp seed flour (Cannabis Sativa L.) (Desnaland LLC, Hlukhiv, Ukraine) was used as an ingredient in the development of recipes. The product characteristics are given in Table 2.

Table 2

The characteristics of physicochemical quality indicators of grinded hemp products (TC U 10.41-39224310-002:2017).

\begin{tabular}{ccc}
\hline Indicator name & Hemp flour & Hemp protein \\
\hline Mass fraction of moisture, \% & 6.5 -no more 7.0 & $6.5-7.0$ \\
Mass fraction of protein, \% & 44.01 -no less 40.00 & $52.14-$ no less 50.00 \\
Mass fraction of oil, \% & 11.65 -no more 16.00 & $10.62-$ no more12.00 \\
Mass fraction of ash, \% & 9.55 -no more 10.0 & $8.84-$ no more 10.0 \\
Mass fraction of cellulose \% & 5.94 -no more 7.0 & 13.88 -no more 15.0 \\
Mass fraction of carbohydrates, \% & 22.35 -no less 20.0 & 8.02 -no less 6.5
\end{tabular}

The samples were examined for nutritional and energy value. The protein content was determined by the Kjeldahl method [8]. To do this, $5 \mathrm{~g}$ of minced meat with $20 \mathrm{ml}$ of concentrated sulfuric acid and $8 \mathrm{~g}$ of catalysts (copper sulfate) were placed in a Kjeldahl flask. The mixture was subjected to wet ashing for $30 \mathrm{~min}$ at a temperature of $350^{\circ} \mathrm{C}$. After ashing, the sample was transferred into a solution of $\mathrm{NaOH}, 33 \%$, distillation was performed on a Kjeldahl apparatus (Fig. 2).

The resulting steam distillate was transferred to a container with a few drops of the Tashiro indicator. Titration was performed with a solution of $0.01 \mathrm{~N}$ sulfuric acid.

Total fat was measured by the Soxhlet method [9]. To do this, $4 \mathrm{~g}$ of the dried sample in a paper cartridge was placed in an extraction flask of the Soxhlet apparatus (Fig. 3).

Petroleum ether with a boiling point of $45^{\circ} \mathrm{C}$ was used for extraction. After repeated extraction, the weight of the paper cartridge with the test sample relative to the constant weight was determined. The difference between the initial and final weight shows the percentage of fat.

Ash was measured after mineralization of the samples in a muffle furnace (Fig. 4) at $520{ }^{\circ} \mathrm{C}$. To do this, a portion of meat-containing bread as $1 \mathrm{~g}$ was accurately transferred to a porcelain crucible and placed in a muffle furnace. Ashing was carried out at a temperature of $520{ }^{\circ} \mathrm{C}$ to the constant weight of the crucible. 


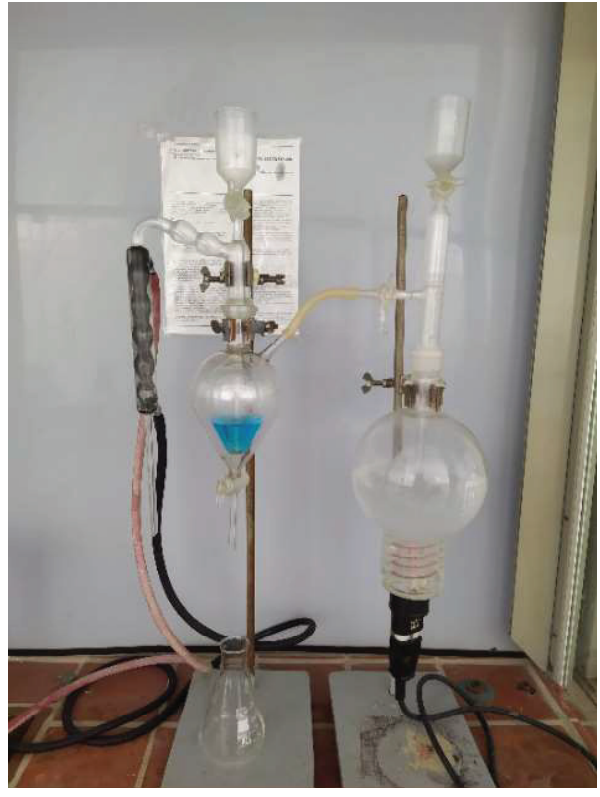

Fig. 2. Kjeldahl apparatus (Germany)

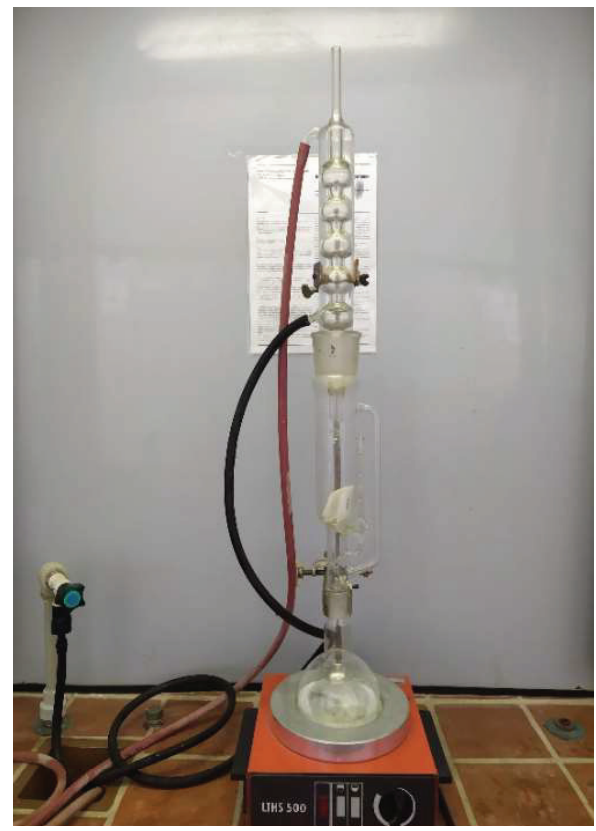

Fig. 3. Soxhlet apparatus (Czechia)

The mass fraction of ash was calculated by the formula, $\%$.

$$
M=100 \times m / m_{1},
$$

where $m / m_{1}$ - ash mass and product portion mass, respectively.

The energy value was calculated according to the system of the total Atwater coefficient. Average energy values are expressed as the number of calories per 1 gram of a macronutrient. The general system of Atwater factors includes energy values of $4 \mathrm{kcal}$ per gram $\left(\mathrm{kcal}^{-1} \mathrm{~g}^{-1}\right)\left(17 \mathrm{~kJ} \cdot \mathrm{g}^{-1}\right)$ for protein, $4 \mathrm{kcal} \cdot \mathrm{g}^{-1}$ for carbohydrates and $9 \mathrm{kcal} \cdot \mathrm{g}^{-1}\left(37 \mathrm{~kJ} \cdot \mathrm{g}^{-1}\right)$ for fat [10]. Functional and technological properties were determined in samples of model minced meat and finished products. 


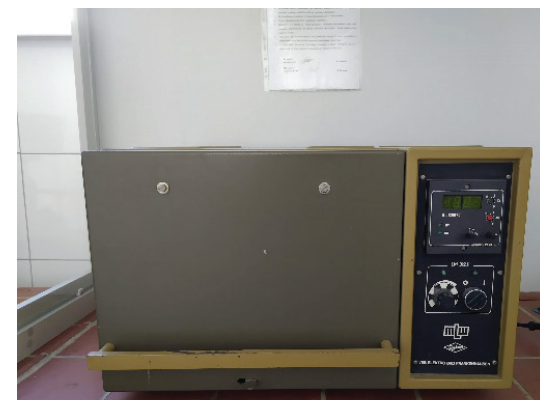

Fig. 4. Muffle furnace (Germany)

The $\mathrm{pH}$ value of the meat was determined using a digital $\mathrm{pH}$ meter $\mathrm{pH}-150 \mathrm{MI}$ (Fig. 5) according to the method [11]. PH measurements were performed after $30 \mathrm{~min}$ of exposure.

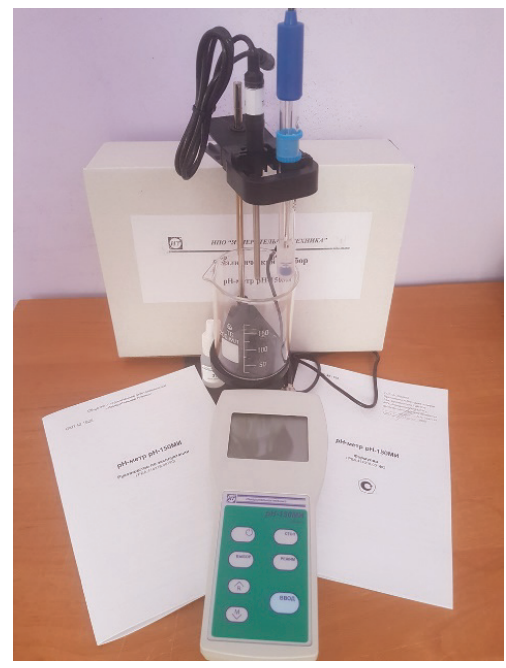

Fig. 5. Digital $\mathrm{pH}$ meter $\mathrm{pH}-150 \mathrm{MI}$

Moisture was determined by drying [12]. To do this, $5 \mathrm{~g}$ of the sample was placed in a box, dried for 1 hour at a temperature of $150^{\circ} \mathrm{C}$.

The water-binding capacity of the minced meat was determined by pressing [11]. For the study, the samples with a mass of $0.3 \mathrm{~g}$ were weighed with an absolute error of $0.001 \mathrm{~g}$, placed on a polyethylene circle, transferred to a circle of filter paper placed on a glass plate, so that the portion of minced meat lays on the filter paper. The top of the plastic circle was covered with a plate, on which a load (weight) weighing $1 \mathrm{~kg}$ was placed. Pressing time is of 10 minutes. After pressing, the mass was removed from the filter paper, the paper was weighed and placed in an oven at a temperature of $105{ }^{\circ} \mathrm{C}$ for drying to the constant weight. In parallel, the mass fraction of moisture was determined in the test sample by drying in an oven at a temperature of $105^{\circ} \mathrm{C}$ to the constant weight.

Water-binding capacity of the minced meat (WBC), as the mass fraction of moisture (relative to the total moisture content in the portion), remaining in the sample after pressing, was determined by formula (2):

$$
W S C=\left[\left(\frac{(B-m)}{100}-8.4 S\right) / m\right] \cdot 100,
$$

where $m$ - portion mass, mg; $B$ - moisture mass fraction in the portion, $\% ; S$ - wet stain area, mg;

The water-retaining capacity of the minced meat was calculated as the difference between the mass fraction of moisture in the minced meat and the amount of moisture, released during heat 
treatment. A portion of finely chopped meat weighing 4-6 g was evenly applied with a glass rod to the inner surface of a wide part of a graduated test tube. The tube was tightly closed with a stopper and placed narrow part down on a water bath at a boiling point for 15 minutes. Then the mass of separated moisture was determined by the number of divisions on the scale of the test tube.

Water-retaining capacity of the meat $(\%)$ was calculated by the formula:

$$
W R C=B-W S C \text {, }
$$

where $B$ - total mass fraction of moisture in the portion, \%; WSC - water-separating capacity of the meat $(\%)$.

WSC is determined by the formula:

$$
W S C=a \cdot n \cdot m^{-1} \cdot 100,
$$

where $a$-graduation of a fat meter; $a=0.01 \mathrm{~cm}^{3} ; n$ - number of divisions on the scale of the fat meter; $m$ - portion mass, $\mathrm{g}$.

To determine the emulsifying capacity $(E C)$, the method [13] was used. $7 \mathrm{~g}$ of the minced meat were grinded in $100 \mathrm{~cm}^{3}$ of water in a homogenizer for $60 \mathrm{~s}$ at a revolution rate of $66.6 \mathrm{~s}^{-1}$. $100 \mathrm{~cm}^{3}$ of refined sunflower oil were added and the mixture was emulsified in a homogenizer at a speed of $1500 \mathrm{rpm}$ for 5 minutes.

The emulsion was poured into 4 calibrated centrifuge tubes and centrifuged in a centrifuge (Fig. 6) at a speed of 500 revolutions per second for 10 minutes

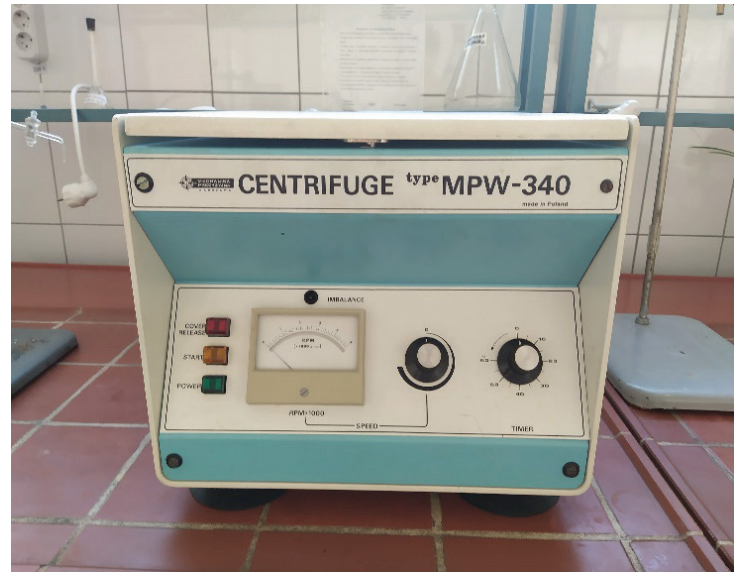

Fig. 6. Centrifuge (Poland)

The volume of emulsified oil after stratification was determined (Fig. 7).

$E C$ was calculated by the formula, \%:

$$
E C=V_{1} / V \times 100,
$$

where $V_{1}$ - volume of emulsified oil, $\mathrm{cm}^{3} ; V$ - total volume of oil, $\mathrm{cm}^{3}$.

The emulsion stability was determined by heating at a temperature of $80{ }^{\circ} \mathrm{C}$ for 30 minutes and cooling with water for 15 minutes [13]. 4 calibrated centrifuge tubes were filled with emulsion and centrifuged at $500 \mathrm{~s}-1$ for $5 \mathrm{~min}$. The volume of the emulsified layer was determined. The emulsion stability (\%) was calculated by the formula:

$$
E S=V_{1} / V_{2} \times 100
$$

where $V_{1}$ - volume of emulsified oil, $\mathrm{cm}^{3} ; V_{2}$ - total volume of emulsion, $\mathrm{cm}^{3}$. 


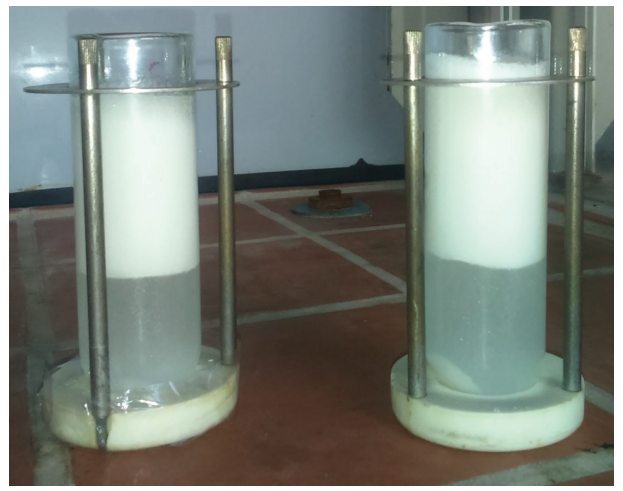

Fig. 7. Stratification of the emulsion at determining the emulsifying capacity

Minced meat plasticity is its ability to withstand a static load of the mass, reduced to a unit of mass $(1 \mathrm{~kg})$. The indicator was determined by the area of the minced meat stain, formed under the action of a static load weighing $1 \mathrm{~kg}$ for 10 minutes [14] and calculated by the formula:

$$
P=\left(B_{m m} \times 1000\right) / m
$$

where $P$ - minced meat plasticity, $\mathrm{cm}^{2} \times \mathrm{kg} / \mathrm{g}, B_{m m}$ - minced meat stain area, $\mathrm{cm}^{2}, 1000$ - conversion factor of the dimensions $\mathrm{mg}$, and $\mathrm{g}$ in $\mathrm{kg}$.

The quality determination of samples of meat-containing breads was carried out by the organoleptic method [15]. Samples of bread were evaluated by 20 tasters, among whom there were students, technicians and teachers of the Faculty of Food Technology of Sumy National Agrarian University. They were selected according to inclusion and exclusion criteria between the ages of 18 and 59. Each taster received coded products on a plastic plate. The evaluated quality features were: appearance, texture, juiciness, taste, aroma and overall acceptability. The sensory analysis was performed on a five-point scale.

Statistical analysis data were processed using Microsoft Excel. All experiments were performed three times. The absolute measurement error was calculated by the Student's t test, the confidence interval $P=0.95$. The data are presented as mean \pm standard deviation of mean: $M \pm m$.

The smallest acceptable difference for tests from one sample was indicated as $5 \%$. The reliability value was chosen as $p<0.05$.

\section{Results}

It was found, that the introduction of turkey MCPM in the recipe in combination with hemp seed flour allows to obtain bread with a mass fraction of protein 18.03-19.53 g/100 g of product. The protein concentration in the experimental samples exceeded the analogue by $3.21-11.79 \%$. The protein content in the experimental products increased in direct proportion to the content of hemp flour. A similar trend was observed in the analysis of fat content. The proportion of fat in meat-containing breads also increased, but due to the inclusion of turkey MCPM in the recipe. The use of turkey MCPM allows to maintain the appropriate biological value at the same level. Turkey MCPM is not inferior to turkey meat of category 1 by the protein content, and the fat content in turkey MCPM is $10.8 \%$ [16]. The inclusion of turkey MCPM significantly affected the mineral content in the developed products. Thus, increasing the proportion of this ingredient in the recipe to $47 \%$ can increase the concentration of macro- and micronutrients in bread to $2.06 \pm 0.05 \mathrm{~g} / 100 \mathrm{~g}$

In the analysis of the FTP of the model minced meat, it was found, that this combination of ingredients allowed to increase the moisture content to $77.03-77.13 \%$, which is $11.16 \%$ higher than in the analogue. The moisture of the minced meat was better bound in the systems with hemp flour and turkey MCPM than in the control. The water-binding capacity of the test samples was on average $17.8 \%$ higher than in the control sample. The ability of the minced meat system to retain water and fat also increased and amounted to 51.06-56.20\% and 63.46-68.49\%, respectively. It 
was proved, that the inclusion of hemp flour in the recipe of baked products at the level of 8-12\% in combination with turkey MCPM in the amount of 41-47\% allows to improve WRC and FRC by $16.23 \%$ and $21.93 \%$, respectively, due to the high protein content both in hemp seeds and in turkey MCPM. This explains the high emulsifying properties of the experimental minced meat. The use of hemp flour in the recipe of baking products in the amount of $10 \%$ led to an increase in EC (emulsifying capacity) by 38.945 , and ES (emulsion stability) - by $20.60 \%$.

The analysis of the FTP stability (functional and technological properties) of the minced meat during heat treatment showed that after baking bread, the moisture content in the finished products was higher in the test samples by $3.88-6.24 \%$, and the output of finished products - by $10.06-11.71 \%$ compared to control.

The results of the organoleptic evaluation of the developed meat-containing breads show that the experimental samples are not inferior to the analogue in terms of consumer characteristics of taste and aroma, consistency and juiciness. In general, the combination of turkey MCPM and hemp flour led to improved physicochemical and technological indicators of the products. The best results were obtained in the product with the combination of MCPM and hemp flour in a ratio of 44:10 at the same concentration of other ingredients.

\section{Conclusions}

It was proved that the joint use of turkey MCPM and hemp flour in meat-containing breads allows to produce goods with high nutritional characteristics. The use of hemp flour in the formulation of baked products with a high content of turkey MCPM improves the functional, technological, nutritional and organoleptic properties of the products. The increase in protein content by $3.21-11.80 \%$, fat - by $47.84-56.83 \%$, energy value - by $26.52-30.23 \%$ was determined.

The high efficiency of combining turkey MCPM with hemp seed flour was confirmed in the study of the functional and technological properties of the model minced meat. MCPM ratio: hemp seed flour 41: 8, 44:10, 47:12 improves the water- binding capacity by $13.46-22.15 \%$, water-retaining capacity - by $10.34-21.43 \%$, fat-retaining capacity - by $17.2-26.9 \%$.

It was established, that the best indicators of functional and technological properties of minced meat and finished products are obtained by including $44 \%$ of turkey of mechanical crumbing and $10 \%$ of hemp flour in the recipe of meat-containing bread. The results of the organoleptic analysis of the developed breads confirmed their high consumer value.

The obtained results allow to recommend mass production of the developed meat-containing breads with hemp flour and turkey meat of mechanical crumbing.

\section{References}

[1] Granato, D., Barba, F. J., Bursać Kovačević, D., Lorenzo, J. M., Cruz, A. G., Putnik, P. (2020). Functional Foods: Product Development, Technological Trends, Efficacy Testing, and Safety. Annual Review of Food Science and Technology, 11 (1), 93-118. doi: http://doi.org/10.1146/annurev-food-032519-051708

[2] Pogorzelska-Nowicka, E., Atanasov, A., Horbańczuk, J., Wierzbicka, A. (2018). Bioactive Compounds in Functional Meat Products. Molecules, 23 (2), 307. doi: http://doi.org/10.3390/molecules23020307

[3] Callaway, J. C. (2004). Hempseed as a nutritional resource: An overview. Euphytica, 140 (1-2), 65-72. doi: http://doi.org/10.1007/ s10681-004-4811-6

[4] Zając, M., Guzik, P., Kulawik, P., Tkaczewska, J., Florkiewicz, A., Migdał, W. (2019). The quality of pork loaves with the addition of hemp seeds, de-hulled hemp seeds, hemp protein and hemp flour. LWT, 105, 190-199. doi: http://doi.org/10.1016/ j.lwt.2019.02.013

[5] Wang, Q., Xiong, Y. L. (2019). Processing, Nutrition, and Functionality of Hempseed Protein: A Review. Comprehensive Reviews in Food Science and Food Safety, 18 (4), 936-952. doi: http://doi.org/10.1111/1541-4337.12450

[6] Korus, J., Witczak, M., Ziobro, R., Juszczak, L. (2017). Hemp (Cannabis sativa subsp. sativa) flour and protein preparation as natural nutrients and structure forming agents in starch based gluten-free bread. LWT, 84, 143-150. doi: http://doi.org/ 10.1016/j.lwt.2017.05.046

[7] Bozhko, N., Tischenko, V., Pasichnyi, V., Yuschko, M., Zhukova, Y., Popova, E. (2018). Study of functional and technological indices of meat-containing loaf with Muscovy duck meat and white carp. Scientific Messenger of LNU of Veterinary Medicine and Biotechnologies. Series: Food Technologies, 20 (85), 19-23. doi: http://doi.org/10.15421/nvlvet8504 
[8] Miaso ta miasni produkty. Vyznachennia vmistu azotu (kontrolnyi metod) (ISO 937:1978, IDT): DSTU ISO 937:2005 (2007). Kyiv: Derzhspozhyvstandart Ukrainy, 10. Available at: http://online.budstandart.com/ua/catalog/doc-page?id_doc $=82211$

[9] Miaso ta miasni produkty. Metod vyznachennia zahalnoho vmistu zhyru (ISO 1443:1973, IDT): DSTU ISO 1443:2005. [Chynnyi vid 01-03-08] (2007). Kyiv: Derzhspozhyvstandart Ukrainy, 9. Available at: http://online.budstandart.com/ua/catalog/ doc-page?id_doc $=82655$

[10] FAO. (2003). Food energy - methods of analysis and conversion factors. Rome. Available at: http://www.fao.org/3/y5022e/ y5022e00.htm

[11] Pasichniy, V., Polumbryk, M. (2016). Collagen containing mixtures impact on sensory properties of chicken forcemeat systems. Scientific Messenger of LNU of Veterinary Medicine and Biotechnologies. Series: Food Technologies, 18 (2), $150-152$. doi: http://doi.org/10.15421/nvlvet6831

[12] DSTU ISO 1442:2005 Miaso ta miasni produkty. Metod vyznachennia vmistu volohy (ISO 1442:1997, IDT). [Chynnyi vid 01-0407] (2007). Kyiv: Derzhspozhyvstandart Ukrainy, 9. Available at: http://online.budstandart.com/ua/catalog/doc-page?id_doc=82535

[13] Antipova, L. V., Glotova, I. A., Rogov, I. A. (2001). Metody issledovaniya myasa i myasnykh produktov. Moscow: Kolos, 576. Available at: https://www.studmed.ru/antipova-lv-glotova-ia-rogov-ia-metody-issledovaniya-myasa-i-myasnyh-produktov_98b69b1f26b.html

[14] Strashynskiy, I., Fursik, O., Pasichniy, V., Marynin, A., Goncharov, G. (2016). Influence of functional food composition on the properties of meat mince systems. Eastern-European Journal of Enterprise Technologies, vol. 6, p. 53-58. https://doi.org/ 10.15587/1729-4061.2016.86957

[15] DSTU 4823.2:2007 Produkty m’yasni. Orhanoleptychne otsiniuvannia pokaznykiv yakosti. Chastyna 2. Zahalni vymohy. [Chynnyi vid 01-01-09]. (2007). Kyiv: Derzhspozhyvstandart Ukrainy, 11. Available at: http://online.budstandart.com/ua/ catalog/doc-page?id_doc $=83084$

[16] Makhonyna, V. N., Roslykov, D. A. (2013). K voprosu otsenki kachestva myasa ptitsy mekhanicheskoy obvalki. Ptitsa i ptitseprodukty, 13, 28-30. Available at: http://www.vniipp.ru/images/statya/0113/t28.pdf

How to cite: Bozhko, N., Pasichnyi, V., Tischenko, V., Marynin, A., Shubina, Y., Strashynskyi, I. (2021). Development of meat-containing breads with hemp seed flour and turkey meat of mechanical crumbing. EUREKA: Life Sciences, 4, 34-42. doi: https://doi.org/ 10.21303/2504-5695.2021.001977 